\title{
Biofilm-specific uptake does not explain differences in whole-stream DOC tracer uptake between a forest and an agricultural stream
}

\author{
D. Graeber $(\mathbb{D} \cdot$ B. Gücker $(\mathbb{D} \cdot$ R. Wild $(\mathbb{D} \cdot$ N. S. Wells $(\mathbb{D} \cdot$ C. Anlanger $(\mathbb{D} \cdot$ \\ N. Kamjunke $(\mathbb{D} \cdot$ H. Norf $(\mathbb{D} \cdot$ C. Schmidt $(\mathbb{D} \cdot$ M. Brauns $(\mathbb{C}$
}

Received: 19 September 2018/Accepted: 26 May 2019/Published online: 3 June 2019

(C) The Author(s) 2019

\begin{abstract}
Benthic biofilms are often assumed to control terrestrially-derived dissolved organic carbon (tDOC) uptake in streams. We tested this by comparing ${ }^{13} \mathrm{C}$-enriched ryegrass leachate uptake in an agricultural and a forest stream, hypothesizing that a greater abundance of autotrophic biofilms in the agricultural stream would cause its whole-stream tDOC uptake to be comparatively low. We measured whole-stream and biofilm tDOC tracer uptake, metabolism, bacterial and algal diversity, and nutrient
\end{abstract}

Responsible Editor: Jonathan Sanderman.

Electronic supplementary material The online version of this article (https://doi.org/10.1007/s10533-019-00573-6) contains supplementary material, which is available to authorized users.

\section{Graeber $(\bowtie)$}

Department of Aquatic Ecosystem Analysis, Helmholtz Centre for Environmental Research - UFZ, Magdeburg, Germany

e-mail: daniel.graeber@ufz.de

\section{B. Gücker}

Department of Geosciences, Federal University of São João del-Rei, São João Del-Rei, Brazil

R. Wild · C. Anlanger · N. Kamjunke ·

H. Norf · M. Brauns

Department of River Ecology, Helmholtz Centre for

Environmental Research - UFZ, Magdeburg, Germany status of benthic epilithic biofilms, and assessed whole-stream hydromorphology. Whole-stream uptake of tDOC was six times lower in the agricultural $\left(3.0 \mathrm{mg} \mathrm{m}^{-2} \mathrm{day}^{-1}\right)$ than in the forest $\left(19.0 \mathrm{mg} \mathrm{m}^{-2}\right.$ day $^{-1}$ ) stream, and tDOC uptake velocity indicated lower tDOC demand in the agricultural $\left(1.2 \mathrm{~mm} \mathrm{~min}^{-1}\right)$ than in the forest $\left(1.9 \mathrm{~mm} \mathrm{~min}^{-1}\right)$ stream. The agricultural stream differed from the forest stream by slightly lower transient storage capacity and higher benthic biofilm bacterial abundance and production, lower biofilm biomass and lower biofilm molar C:N, C:P, and N:P ratios. Changes in epilithic biofilms contributed little to the differences in whole-stream tDOC tracer uptake between streams, as biofilm tDOC uptake only amounted to $4 \%$ and $13 \%$ of whole-stream uptake in the forest and agricultural

N. S. Wells

Centre for Coastal Biogeochemistry, School Environment, Science \& Engineering, Southern Cross University, Military Rd, East Lismore, Australia

\section{N. S. Wells}

Department of Catchment Hydrology, Helmholtz Centre for Environmental Research - UFZ, Halle (Saale), Germany

C. Schmidt

Department of Hydrogeology, Helmholtz Centre for Environmental Research - UFZ, Leipzig, Germany 
stream, respectively. This comparison of a forest and an agricultural stream suggests that agricultural stressors have the potential to diminish both whole-stream tDOC uptake and uptake efficiency. Furthermore, the weak link between biofilm and whole-stream tDOC uptake implies that benthic biofilms characteristics are poor predictors for human impacts on $\mathrm{tDOC}$ uptake in agricultural streams and that hot spots of tDOC uptake are likely situated in the hyporheic zone or in the stream water column.

Keywords Epilithic biofilms · Hydromorphology · Land use $\cdot$ Ecological stoichiometry $\cdot$ Stable isotope addition

\section{Introduction}

The largest part of organic carbon in fluvial ecosystems is usually dissolved organic carbon (DOC) from terrestrial sources (Tank et al. 2010). This terrestriallyderived DOC ( $\mathrm{tDOC}$ ) drives the metabolism of stream ecosystems, and shapes stream microbial food webs (Prairie 2008; Stanley et al. 2012).

Stream tDOC is assumed to be primarily processed by biofilms (Romaní et al. 2004). Biofilms are substratum-associated consortia of microorganisms (microalgae, bacteria, fungi, protozoans, and small metazoans) embedded in extracellular polymeric substances (EPS) (Romani et al. 2004; Battin et al. 2016). Epilithic biofilm bacteria can contribute substantially to DOC processing, particularly in small streams where the stream bed is often covered by coarse mineral substrates (Battin et al. 2016). For example, ${ }^{13} \mathrm{C}$-enriched acetate additions showed that epilithic biofilm bacteria consume DOC and are consumed by benthic invertebrates (Collins et al. 2016). Thus, changes in stream epilithic biofilm characteristics should affect in-stream DOC uptake (Qu et al. 2017), with cascading effects on higher trophic levels. This is particularly relevant to land-use change in the riparian zone of streams, which alters the hydrodynamics, light, and nutrient status (Gücker et al. 2009; Boëchat et al. 2011) that define stream biofilm structure (Battin et al. 2016).

Agriculture changes streams physically by straightening, incising, damming and other impacts (Blann et al. 2009). At the same time, fertilization and riparian clearcutting increase nutrient $(\mathrm{N}$ and $\mathrm{P})$ concentrations and light availability, while reducing coarse particular organic matter (CPOM) abundance (Bernot et al. 2010). These modifications may alter agricultural stream tDOC uptake by two mechanisms. First, hydromorphologically: channel simplification decreases transient storage zone size (Gücker and Boëchat 2004; Bernot et al. 2006) and minimizes contact (both temporal and spatial) between benthic biofilms and water column nutrients. These hydromorphological modifications can decrease biological nutrient processing rates (Battin et al. 2016) and set the upper physical limit for nutrient removal (Grant et al. 2018). Second, the high light and nutrient availability in agricultural streams supports a large benthic, autotrophic biofilm biomass (Dodds et al. 2002) and stimulates benthic gross primary production (GPP) (Bernot et al. 2010). Increased autochthonous production of labile DOC can then reduce community demand for allochthonous tDOC (Wagner et al. 2015). At the same time, increased agricultural nutrient loadings can alter stream biofilm properties like total biomass, taxonomic and biochemical composition (Dodds et al. 2002; Johnson et al. 2009b). Interactions between the effects of altered hydromorphology and biology are thus likely active in agricultural streams (Gücker et al. 2009; Boëchat et al. 2011). However, their combined effect on agricultural stream tDOC uptake is unknown.

Besides affecting stream hydromorphology and biology, agriculture also changes tDOC composition. The tDOC in agricultural streams is molecularly more similar to microbially-derived organic matter than tDOC in unmodified streams. This shift is detectable via fluorescence indices (fluorescence index, beta:alpha index; Wilson and Xenopoulos 2009; Graeber et al. 2015a, b; Heinz et al. 2015), the occurrence of reduced quinones (Williams et al. 2010; Graeber et al. 2012), and the low tDOC to dissolved organic $\mathrm{N}$ ratio (Graeber et al. 2015a, b; Heinz et al. 2015). In combination, the quality indicators indicate that $\mathrm{tDOC}$ in agricultural streams is a more biological reactive, potentially increasing tDOC uptake (Wilson and Xenopoulos 2009; Williams et al. 2010; Graeber et al. 2012, 2015b; Heinz et al. 2015). More reactive agricultural stream tDOC would affect the role of stream biofilms and hydromorphology in tDOC uptake. Such changes in tDOC reactivity would confound efforts to untangle the effects of stream 
biofilm attributes and hydromorphology on agricultural stream tDOC uptake.

Knowledge of whole-stream DOC uptake largely comes from tracer additions using simple, highly labile 'model' compounds. The usage of model compounds exacerbates the difficulty in predicting how agricultural land use affects whole-stream and biofilm tDOC uptake vis-à-vis changes in biofilm structures. For example, Johnson et al. (2009a) found no significant effect of agriculture on whole-stream DOC uptake rates using acetate and glucose as model substances. Conversely, Mineau et al. (2013) found that whole-stream uptake of natural, complex DOC from leaf leachates was positively correlated with the concentrations of reactive nitrogen and phosphorus. Differences in benthic biofilm quantity, composition or functioning may explain the discrepancies between studies, but benthic biofilm characteristics were not yet related to whole-stream DOC uptake.

To untangle the controls on whole-stream and biofilm tDOC uptake in streams, we added ${ }^{13} \mathrm{C}$ enriched leaf leachate from ryegrass as a realistic, complex tDOC source to a forest stream and an agricultural stream. We hypothesized that the tDOC uptake by benthic biofilms in the agricultural stream would be lower than in the forest stream due to a high level of autotrophy caused by high levels of light and nutrients, which, together with reduced transient storage, would lead to a low whole-stream tDOC uptake in the agricultural stream.

\section{Methods}

Site description

We sampled a forest headwater stream (Wormsgraben, $\left.51^{\circ} 46^{\prime} 22.20^{\prime \prime} \mathrm{N}, 10^{\circ} 43^{\prime} 15.11^{\prime \prime} \mathrm{E}\right)$ and an agricultural headwater stream (Hassel, 51 $41^{\prime} 32.31^{\prime \prime} \mathrm{N}$, $\left.10^{\circ} 51^{\prime} 32.82^{\prime \prime} \mathrm{E}\right)$ in the River Bode catchment in Eastern Germany (Wollschläger et al. 2017) (Fig. 1). The streams differed in land use (CORINE land cover maps) (Table 1).

\section{Stable isotope tDOC labeling}

We produced a naturally occurring tDOC tracer from ryegrass (Lolium perenne L.) grown for 4 weeks under an isotopically enriched ${ }^{13} \mathrm{CO}_{2}(99$ at.\%) atmosphere at the IsoLife labeling facility (Wageningen, the Netherlands). We harvested seedlings after 4 weeks, which were frozen until processing. We ground the leaves, stems, and roots, and then cold-water $\left(4^{\circ} \mathrm{C}\right)$ extracted them for $24 \mathrm{~h}$ (Wiegner et al. 2005). This infusion was passed through pre-combusted Whatman $\mathrm{GF} / \mathrm{F}$ filters (nominal pore size $0.7 \mu \mathrm{m}$ ) and stored at $-20{ }^{\circ} \mathrm{C}$ for $\sim 1$ month. The cost of producing enough volume of this realistic tDOC tracer $(72 \mathrm{~L}$ of highly concentrated, 98 at. $\%{ }^{13} \mathrm{C}$ DOC from $250 \mathrm{~g}$ of labelled ryegrass) limited the number of investigated streams.

\section{Experimental design}

We performed the tDOC addition on 28th May 2015 at the agricultural stream, and on 24th June at the forest stream. To separate the effects of water chemistry and hydromorphology on biofilm tDOC uptake, we used parallel experiments in stream-side flumes. These contained the original stream water of the different streams but had identical hydromorphology. At both streams, we installed a stream-side mobile mesocosm (MOBICOS), consisting of a replicated flow-through systems continually supplied with water from the stream (Wollschläger et al. 2017). Each mesocosm contained six flumes (each $300 \times 13 \times 20 \mathrm{~cm}$, length $\times$ width $\times$ depth). Flume discharges were set at $0.35 \mathrm{~L} \mathrm{~s}^{-1}$, and light:dark cycles were set to $16: 8 \mathrm{~h}$. We adjusted light intensity in the containers to reflect differences in natural light intensities measured at the streams, which was higher at the open-canopy agricultural stream (3445 lux) than at the closed-canopy forest stream (655 lux).

We added the tDOC tracer to three of the six flumes in each mesocosm (treatment flumes) at a constantrate addition for approx. $24 \mathrm{~h}$ using a syringe pump (AL 6000, World Precision Instruments, Sarasota, FL, USA). The other three mesocosm flumes served as controls. After passing the flumes, the tracer was routed back into the stream via diffusers (Supplementary Information, Fig. S2), for whole-stream tDOC tracer uptake measurements. The addition gave a calculated increase of DOC concentration by $0.38 \%$ in the forested and by $0.51 \%$ in the agricultural flumes and by $0.005 \%$ or less in the streams themselves.

For whole-stream measurements, we sampled seven stations downstream and one station upstream of the injection site in both streams. In the forest 

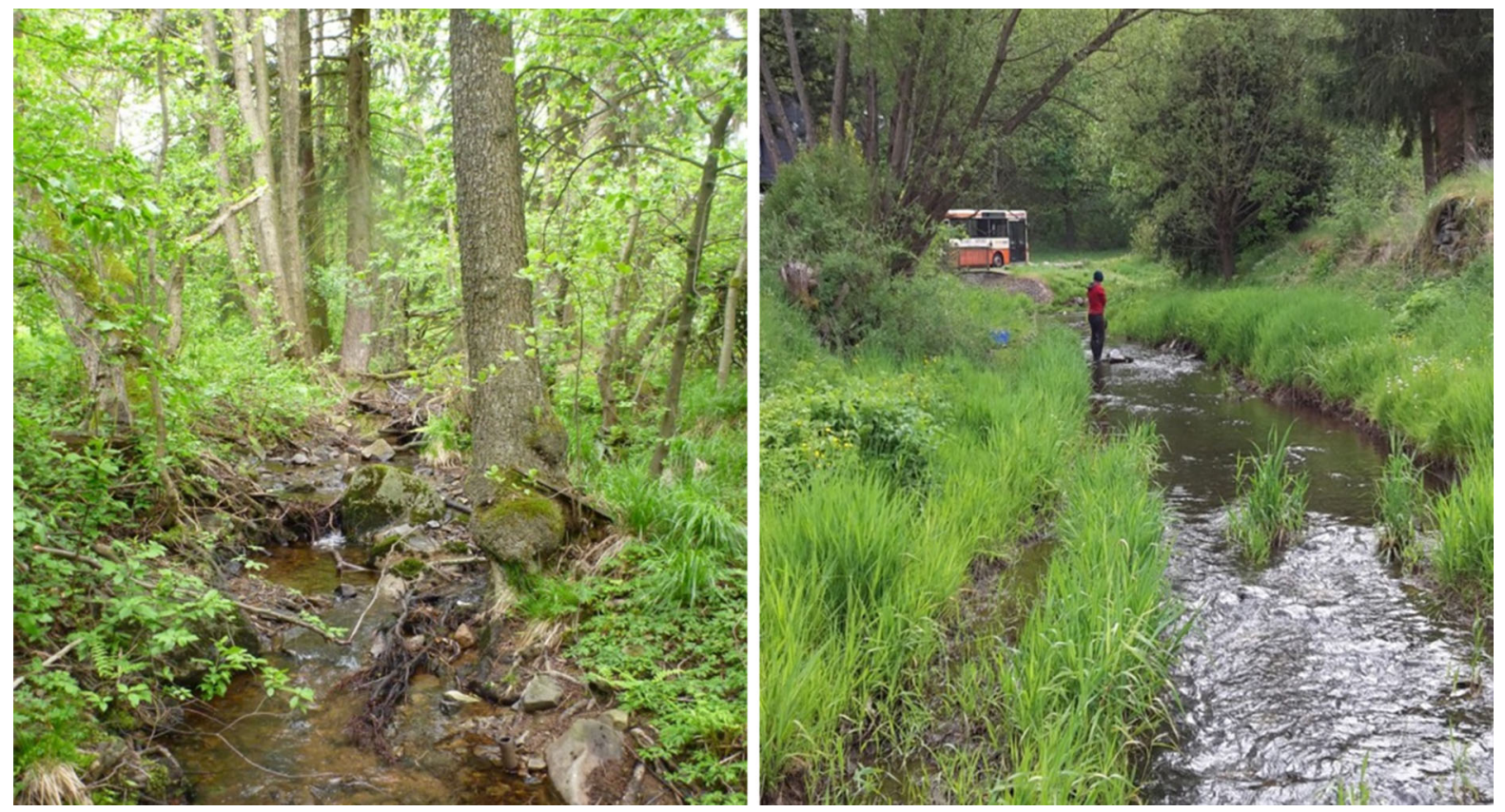

Fig. 1 The studied forest (left) and agricultural (right) stream

Table 1 Catchment land use and stream characteristics before the tDOC addition (mean $\pm 1 \mathrm{SD}$ ) of the studied streams

$\mathrm{TSI}_{\text {norm }}=$ number of advective water transport time scales elapsed between the travel time distribution peak and passage of $99 \%$ of the tracer. The mineral substrate contribution was calculated based on the areal contribution of stones, gravel, coarse and middle sand (see Supplementary Table S2 for details on the areal distribution of substrates)

${ }^{a}$ All replicates were below the quantification limit

\begin{tabular}{|c|c|c|}
\hline Physical & Forest & Agriculture \\
\hline \multicolumn{3}{|l|}{ Land use $(\%)$} \\
\hline Arable/pasture & 0 & 59 \\
\hline Urban & 0 & 3 \\
\hline Forest & 100 & 38 \\
\hline \multicolumn{3}{|l|}{ General stream characteristics } \\
\hline Mineral substrates ( $\%$ benthic area) & 90 & 77 \\
\hline Discharge $\left(\mathrm{L} \mathrm{s}^{-1}\right)$ & 24 & 48 \\
\hline Mean width $(\mathrm{m})(\mathrm{n}=14)$ & $1.5 \pm 0.4$ & $3.7 \pm 0.4$ \\
\hline Mean depth $(\mathrm{cm})(\mathrm{n}=250)$ & $9 \pm 6$ & $20 \pm 20$ \\
\hline Water temperature $\left({ }^{\circ} \mathrm{C}\right)$ & 12 & 14 \\
\hline \multicolumn{3}{|l|}{ Hydromorphology } \\
\hline Specific solute travel time ${ }_{\text {peak }}\left(\mathrm{s} \mathrm{m}^{-1}\right)$ & 8.2 & 5.5 \\
\hline TSI $_{\text {norm }}$ & 10.2 & 8.0 \\
\hline \multicolumn{3}{|l|}{ Nutrients } \\
\hline $\operatorname{DOC}\left(\mathrm{mg} \mathrm{L}^{-1}\right)(\mathrm{n}=2)$ & $5.61 \pm 0.16$ & $4.70 \pm 0.39$ \\
\hline $\mathrm{NH}_{4}-\mathrm{N}\left(\mathrm{mg} \mathrm{L}^{-1}\right)(\mathrm{n}=2)$ & $0.04 \pm 0.03$ & $0.08 \pm 0.04$ \\
\hline $\mathrm{NO}_{3}-\mathrm{N}\left(\mathrm{mg} \mathrm{L}^{-1}\right)(\mathrm{n}=3)$ & $0.64 \pm 0.11$ & $0.88 \pm 0.06$ \\
\hline $\mathrm{DON}\left(\mathrm{mg} \mathrm{L}^{-1}\right)(\mathrm{n}=2)$ & $0.47 \pm 0.09$ & $0.60 \pm 0.08$ \\
\hline $\operatorname{SRP}\left(\mathrm{mg} \mathrm{L}^{-1}\right)(\mathrm{n}=2)$ & $<0.003^{\mathrm{a}}$ & $0.016 \pm 0.005$ \\
\hline
\end{tabular}

stream the seven stations were located 25, 50, 75, 100, 125,150 , and $200 \mathrm{~m}$ downstream from the tracer injection; in the agricultural stream the stations were located 42, 84, 109, 134, 159, 184, and $234 \mathrm{~m}$ downstream from the tracer injection. We located the first stations sufficiently downstream of the 
injection site (25 and $42 \mathrm{~m}$ for the forest and agricultural stream, respectively) to ensure complete mixing of tracer and stream water.

Sampling and analysis

\section{Whole stream tDOC uptake}

We collected samples for DOC concentrations, ${ }^{13} \mathrm{C}$ DIC and ${ }^{13} \mathrm{C}$-DOC in triplicates $24-\mathrm{h}$ after the start of the addition from the eight sampling stations in each stream. A 5-min delay between replicate sampling at each station ensured collection of independent water volumes. We passed DOC and ${ }^{13} \mathrm{C}$-DOC samples through pre-combusted Whatman GF/F filters (Whatman, Inc., Florham Park, NJ, U.S.A.). DOC samples were stored at $4{ }^{\circ} \mathrm{C}$ and analyzed via high temperature oxidation with non-dispersive infrared (NDIR) detection to (DIN EN 1484 1997) within 24 h. Samples for ${ }^{13} \mathrm{C}$-DOC were immediately frozen for later analysis. We used DOC isotopic composition $\left(\delta^{13} \mathrm{C}\right.$-DOC) of both enriched and natural abundance samples was measured with an TIC-TOC analyzer (Aurora 1030 W, OI Analytical, College Station, TX, U.S.A.) coupled in continuous flow mode to a Thermo Scientific Delta V plus isotope ratio mass spectrometer (Thermo Electron Corporation, Waltham, MA, U.S.A.) at the Stable Isotope Facility of the University of Erlangen-Nuremberg. Natural abundance data were normalized to the Vienna Pee Dee Belemnite scale using two in-house reference materials (precision $<0.3 \%$ ). Enriched samples were normalized using a 3-point normalization with $\mathrm{C} 4$ sugar $\left(\delta^{13-}\right.$ $\mathrm{C}=-11.5 \%$ ) and two urea mixed standards $\left(\delta^{13-}\right.$ $\mathrm{C}=+28.3 \%$ and $+195 \%$ ). The mixed standards were prepared from ${ }^{13} \mathrm{C}$-labeled urea and urea with a natural isotope abundance by isotope blending (Carter and Fry 2013). The precision of enriched samples was $<20 \%$.

We calculated whole-stream spiralling metrics, i.e. areal whole-stream tDOC tracer uptake $\left(\mathrm{U}_{\text {tot }}, \mathrm{mg}{ }^{13} \mathrm{C}\right.$ DOC $\mathrm{m}^{-2}$ day $\left.^{-1}\right)$, uptake length $\left(\mathrm{S}_{\mathrm{w}}, \mathrm{m}\right)$ and uptake velocity $\left(\mathrm{V}_{\mathrm{f}}, \mathrm{mm} \mathrm{min}^{-1}\right)$ following Tank et al. (2000) and Mulholland et al. (2004) (see Supplementary Material for details).

We estimated mineralization of our tDOC tracer by measuring ${ }^{13} \mathrm{C}$-DIC from samples taken for ${ }^{13} \mathrm{C}$-DOC. The sample was reacted with $0.5 \mathrm{~mL}$ of $5 \%$ phosphoric acid at $70{ }^{\circ} \mathrm{C}$ for $2 \mathrm{~min}$ and carbon stable isotopes of the released $\mathrm{CO}_{2}$ were measured as outlined above. Mineralization rates were calculated as outlined in the Supplementary Material.

\section{Biofilm tracer uptake}

Areal uptake of tDOC tracer into epilithic biofilms $\left(\mathrm{U}_{\mathrm{b}}, \mathrm{mg}{ }^{13} \mathrm{C}\right.$-DOC $\mathrm{m}^{-2}$ day $\left.^{-1}\right)$ in flumes and streams was calculated from samples collected at the start of the experiment, and after six, 12, 18 and $24 \mathrm{~h}$ (see Supplementary Material for details). We only use the 24-h measurements for comparison with $U_{\text {tot }}$ and for the correlations to biofilm characteristics. For measuring $\mathrm{U}_{\mathrm{b}}$, we placed 40 unglazed ceramic tiles 4 weeks before the experiments to allow for colonization with natural biofilm communities. We used tiles downstream from injection sites (stream tiles) and in treatment flumes (flume tiles) to calculate biofilm uptake rates. We used tiles in the control flumes or upstream of the tracer addition to control for the effects of the tDOC tracer on biofilm attributes. We collected biofilms from triplicate natural pebbles at the first downstream station at the same times as we sampled the tiles. Biofilm samples were collected scraping off biofilms from the tiles with a razor blade, and we immediately froze and stored them at $-20{ }^{\circ} \mathrm{C}$ until processing.

We quantified biofilm biomass as dry weight and ash-free dry mass (AFDM) by weighing, combusting $\left(6 \mathrm{~h}\right.$ at $\left.540{ }^{\circ} \mathrm{C}\right)$ and reweighing biofilm samples. Elemental carbon concentrations were measured using standard methods (DIN EN 1484 1997; ISO 6878 2004). Biofilm $\delta^{13} \mathrm{C}$ (natural abundance and enriched) was analyzed on a Thermo-Finnigan Flash 2000 elemental analyzer connected to a Delta V Advantage mass spectrometer (Thermo Electron Corporation) using lab standards as described above. Analytical precision of solid samples was $<0.2 \%$ o for natural abundance ${ }^{13} \mathrm{C}$ and $<25 \%$ for enriched ${ }^{13} \mathrm{C}$. We calculated tDOC uptake into flume and stream biofilms for each time point as outlined in the Supplementary Material.

\section{Benthic biofilm attributes}

For benthic biofilm attributes, we performed all the measurements on samples collected before and after the tDOC addition from three tiles from both the upstream and first downstream station, as well as on 
one tile from each treatment and control flume. We measured biofilm chlorophyll a (Chl-a) by suspending biofilm samples into 90\% EtOH and measuring Chl-a concentration photometrically (AquaFluor ${ }^{\circledR}$ Handheld Fluorometer, Turner Design, San Jose, CA, U.S.A.). We quantified biofilm biomass as dry weight and ash-free dry mass (AFDM) by weighing, combusting $\left(6 \mathrm{~h}\right.$ at $\left.540{ }^{\circ} \mathrm{C}\right)$ and reweighing biofilm samples. Using standard elemental analysis, we determined molar ratios of carbon (C), nitrogen (N) and phosphorus (P) from homogenized samples (DIN EN 1484 1997; ISO 6878 2004). At the field sites, we measured biofilm metabolism as dissolved oxygen (DO) production and consumption with a flow-through chamber benchtop system (see Supplementary Material for details). As described in Kamjunke et al. (2015a), we counted the abundance of bacteria from replicate, formalin fixed samples (3.7\% final concentration) after staining with acridine orange with an epifluorescence microscope (Axioskop2, Zeiss) and measured the secondary production of benthic bacteria using the leucine technique (Supplementary Material). We assessed the assemblage structure of biofilm bacteria and algae by terminal restriction fragment length polymorphism (T-RFLP). Briefly, we extracted community DNA using standard procedures and used the number of operational taxonomic units (OTUs) to describe bacterial or algal richness in a sample (Supplementary Material).

\section{Stream characterization}

We took samples for nitrate, ammonium, SRP and total dissolved nitrogen concentrations once prior (Table 1) and once during the experiments. Samples were taken both up- and downstream of the tDOC tracer additions, and in the treatment and control stream-side flumes to assess chemical differences between the streams and to test if the tDOC addition altered the water chemistry. Samples for total dissolved nitrogen (TDN), nitrate, ammonium, and SRP were filtered through polycarbonate $0.2 \mu \mathrm{m}$ filters (membraPure, Berlin, Germany) and stored at $4{ }^{\circ} \mathrm{C}$ until analysis. We determined nitrate and TDN concentrations photometrically (quantification limit $(\mathrm{QL})=0.042 \mathrm{mg} \mathrm{N} \mathrm{L}^{-1}$ ), applying the segmented flow technique according to the German national standard method (ISO 13395 1996) and ammonium concentrations $\left(\mathrm{QL}=0.011 \mathrm{mg} \mathrm{N} \mathrm{L}{ }^{-1}\right)$ via ion-chromatography (ISO 14911 1998). We measured SRP concentrations using the ammonium molybdate spectrometric method $\left(\mathrm{QL}=0.003 \mathrm{mg} \mathrm{L}^{-1}\right)$ (ISO 6878 2004). Samples for TDN were digested with potassium persulfate before the measurements. Dissolved organic nitrogen (DON) concentration was calculated as DON $=$ TDN-nitrate-ammonium.

We estimated areal coverage of stream habitats every $10 \mathrm{~m}$ along the experimental stretches of the two streams, and measured stream width and depth at 14 equidistant cross-sections over the sampled lengths. Stream discharge was determined by monitoring electrical conductivity (EC) at the first and last downstream site of both streams using conductivity sensors (EXO2 multiparameter probe, YSI, Ohio) following a $2 \mathrm{~h}$ sodium chloride $(\mathrm{NaCl})$ constant rate addition The $\mathrm{NaCl}$ injection sites matched the tDOC injection sites. Pump flow rates and tracer concentrations were $0.49 \mathrm{~L} \mathrm{~min}^{-1}$ and $0.30 \mathrm{~kg} \mathrm{~L}^{-1}$, and $0.22 \mathrm{~L} \mathrm{~min}^{-1}$ and $0.22 \mathrm{~kg} \mathrm{~L}^{-1}$ for the agricultural and forest stream, respectively. We calibrated EC of the two sensors before the experiment as a function of the concentration of dissolved $\mathrm{NaCl}$. The $\mathrm{NaCl}$ addition raised specific conductivity from 89 to $276 \mu \mathrm{S} \mathrm{cm}$ (forest stream) and from 233 to $335 \mu \mathrm{S} \mathrm{cm}$ (agricultural stream).

Based on the conservation of mass of the solute tracer, we calculated stream discharge from the EC time series at the last downstream site. We calculated the solute travel time distribution (TTD, see Supplementary Material) and calculated the specific solute travel time in $\mathrm{s} \mathrm{m}^{-1}$ based on the distance from the upstream to the downstream station and the travel time it of the TTD peak between those stations. We estimated transient storage with a TTD metric, the normalized transient storage zone index $\left(\mathrm{TSI}_{\text {norm }}\right)$ (Gooseff et al. 2007; Mason et al. 2012; Ward et al. 2013). TSI $_{\text {norm }}$ is defined as $\left(t_{99}-t_{\text {peak }}\right) / t_{\text {peak }}$, where $t_{99}$ is the time after injection at which $99 \%$ of the tracer has passed the downstream end of the reach and $t_{\text {peak }}$ is the time after injection at which the peak of the TTD has passed the downstream end of the reach. The subtraction of $t_{\text {peak }}$ from $t_{99}$ provides a simple metric for transient storage and the normalization with $t_{\text {peak }}$ makes it comparable between streams. In the given form, $\mathrm{TSI}_{\text {norm }}$ represents the number of advective timescales elapsed between $t_{\text {peak }}$ and $t_{99}$ and describes processes other than advection on creating tailing of 
the TTD, which we define as transient storage (Ward

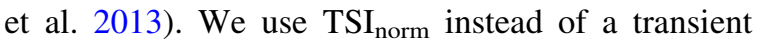
storage model (e.g. OTIS; Runkel 1998), since parameter estimates for transient storage zone area in such models can be highly uncertain and should only be used together with assessments of parameter sensitivity (Kelleher et al. 2013), whereas TSI $\mathrm{Torm}_{\text {is }}$ an indicator of transient storage with high sensitivity (Mason et al. 2012) and low uncertainty (Ward et al. 2013).

\section{Statistical analysis}

To test effects of the stream identity (agricultural versus forest stream) on $U_{\text {tot }}, V_{f}$ and $S_{w}$, we applied a type II one-way analysis of variance (ANOVA, Im and Anova functions, base, and car package in R) (Fox and Weisberg 2011; R Core Team 2019) to the triplicate samples collected $24 \mathrm{~h}$ after the tracer additions. We assumed that the replicates represent independent water volumes, based on the 5-min delay between their collections. In one case, we found non-normally distributed model residuals $\left(\mathrm{S}_{\mathrm{W}}\right)$, which were corrected by $\ln$-transformation.

We used a type II two-way ANOVA with interaction to test for effects of stream identity (agricultural versus forest stream) and experimental design (wholestream vs. stream-side flumes) on $U_{b}$. When the variance of the samples was heterogeneous, we used the $\mathrm{HC} 4$ estimator to create a heteroscedasticitycorrected coefficient covariance matrix (parameter white.adjust = "hc4" in the Anova function) (CribariNeto 2004).

To place our results in a broader context, we synthesized published measurements of DOC $V_{f}$ from studies comparing agricultural with natural streams. This review enabled us to test whether the nature of the tracer, i.e. simple compounds (sensu Mineau et al. 2016) versus leachates affected DOC uptake. The effect size of agricultural land use on DOC $V_{f}$ $\left(\mathrm{mm} \mathrm{min}^{-1}\right)$ was calculated as the natural logarithm of the response ratio, i.e. $V_{f}$ of the agricultural stream divided by $V_{f}$ of a reference stream (reference stream type depended on study). The variance associated with each response ratio was calculated from the standard deviation (SD) associated with each $\mathrm{V}_{\mathrm{f}}$ value. Hence, we only included replicated studies presenting data with at a measure of uncertainty. We calculated the average effect size across all simple DOC compounds as the inverse variance-weighted average of the individual values. Finally, we fitted a mixed-effects meta-regression model to the data using substance as moderator and compared effect sizes using Tukey contrasts. These tests were conducted in $\mathrm{R}$ using the "metafor" (Viechtbauer 2010) and "multcomp" package (Hothorn et al. 2008).

We analysed biofilm characteristics (gross primary production on tiles, respiration on tiles, Chl-a, AFDM, OTU richness of bacteria, OTU richness of algae, bacterial density, bacterial production, biofilm molar $\mathrm{C}: \mathrm{N}, \mathrm{C}: \mathrm{P}$ and $\mathrm{N}: \mathrm{P}$ ) from the stream tiles and flume tiles with permutational analyses of variance (PERMANOVA, adonis function, vegan package in R) (Oksanen et al. 2015). With the PERMANOVA, we tested for effects of stream identity (forest or agricultural stream), placement of the tiles (stream tiles or flume tiles), temporal differences (before and after ${ }^{13} \mathrm{C}$ DOC injections), and effects of DOC enrichment with treated and non-treated tiles (placed either downstream or upstream the DOC enrichment, or in treatment or control flumes). Here, we tested for main effects and interaction effects and used Euclidean distances for the dissimilarity matrix. Before applying the PERMANOVA, we scaled all variables to unit variance (scale function base package in $\mathrm{R}$ ). The primary assumption of the PERMANOVA is that the observations are exchangeable under the null hypothesis, an assumption which our experimental design fulfilled (Anderson 2001).

We conducted a principal component analysis (PCA) with the rda function (Oksanen et al. 2015) to further investigate differences in biofilm structure between the streams treated and non-treated tiles (placed either downstream or upstream the DOC enrichment, or in treatment or control flumes). We separated the data into the samples from stream tiles and flume tiles to increase the clarity of the PCA ordinations. We scaled the datasets to unit variance before conducting the PCA analyses. Based on Scree plots, we kept the first two principal components of the PCAs (Quinn and Keough 2002). Since we used the PCA only for exploratory purposes, there was no need for the data to be normally distributed (Quinn and Keough 2002).

We tested correlations between all biofilm structure variables and $\mathrm{U}_{b}$ to investigate potential effects of biofilm structure on biofilm DOC uptake. This produced eleven correlations. We used Spearman 
rank correlations (cor.test function, base package in $\mathrm{R}$ ) (Quinn and Keough 2002) since the residuals of linear regressions were often not normally distributed and because we were not interested in the shape of the correlation. We only plotted correlations exhibiting a significant effect $(\mathrm{p}<0.05)$.

\section{Results}

\section{Stream characteristics}

Stones, gravel, coarse and middle sand dominated the benthic zone of both streams (Table 1, Table S2). The forest stream was narrower, shallower and had a lower discharge than the agricultural stream (Table 1). Both streams had similar DOC and nitrate concentrations, but the agricultural stream had slightly higher ammonium and distinctly higher soluble reactive phosphorus (SRP) concentrations (Table 1). Water temperature was $2{ }^{\circ} \mathrm{C}$ higher in the agricultural stream (Table 1). Specific solute travel times were higher in the forest stream than in the agricultural stream (Table 1). The higher $\mathrm{TSI}_{\text {norm }}$ of the forest stream than in the agricultural stream indicated a higher solute transient storage in the forest stream (Table 1, Supplementary Information, Fig. S1).

\section{DOC uptake}

Additions of ${ }^{13} \mathrm{C}$-labeled ryegrass leachate increased stream water $\delta^{13} \mathrm{C}$-DOC from $-27 \pm 0$ to $+3400 \pm 980 \%$ (flume) and from $-27 \pm 0$ to $+190 \pm 8 \%$ (whole-stream) of the forest stream. In the agricultural stream, additions raised stream water $\delta^{13} \mathrm{C}$-DOC from $-28 \pm 0$ to $+2400 \pm 51 \%$ in the flume and from $-27 \pm 0$ to $+19 \pm 2 \%$ in the stream. Tracer flux to flumes did not substantially vary over time (Supplementary Information, Fig. S2) and declined with distance downstream in both streams (Fig. 2). Spiraling metrics differed between streams: $\mathrm{S}_{\mathrm{w}}$ was longer, and $\mathrm{V}_{\mathrm{f}}$ and $\mathrm{U}_{\text {tot }}$ were lower in the agricultural than in the forest stream (Table 2). Whole-stream net tDOC mineralization rates were lower in the agricultural stream than in the forest stream, but the relative contribution of mineralization to $U_{\text {tot }}$ was higher in the agricultural stream (Table 2).

The biofilm biomass labelled by the ${ }^{13} \mathrm{C}$ tracer increased over experimental time, but did not reach

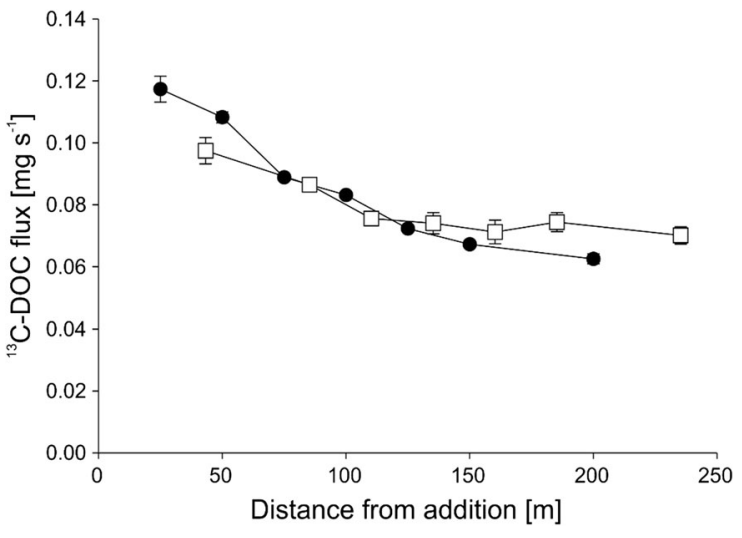

Fig. 2 Background-corrected ${ }^{13} \mathrm{C}$-DOC tracer flux along the studied reaches of the forest stream (dots) and the agricultural stream (rectangles). Shown are means \pm 1 SD from triplicate measurements conducted after $24 \mathrm{~h}$ of additions

equilibrium (Fig. 3). $\mathrm{U}_{\mathrm{b}}$ was higher on stream tiles than on flume tiles (ANOVA, $F=12.2, \mathrm{df}=1$, $\mathrm{p}=0.007$ ) (Table 2). $\mathrm{U}_{\mathrm{b}}$ by epilithic biofilms on stream tiles did not significantly differ between streams (ANOVA, $\mathrm{F}=4.6, \mathrm{df}=1, \mathrm{p}=0.067$, Table 2). However, the contribution of $U_{b}$ to $U_{\text {tot }}$, was only $4 \%$ and $13 \%$ in the two streams, respectively (Table 2). This contribution would be similar or even lower for natural pebbles sampled from the stream, as their ${ }^{13} \mathrm{C}$ concentration was similar or lower than the one of the tiles at all sampling times during the experiments (Supplementary information, Fig. S4).

For a wider comparison of whole-stream DOC uptake in agricultural versus reference streams, we found three studies satisfying our inclusion criteria representing a total of 59 DOC $\mathrm{V}_{\mathrm{f}}$ measurements. These studies used simple DOC compounds, i.e. acetate, arabinose and glucose, but we did not find any study using DOC from leachates (Fig. 4). Agricultural land use reduced DOC $\mathrm{V}_{\mathrm{f}}$ of arabinose and glucose and increased DOC $\mathrm{V}_{\mathrm{f}}$ for acetate. However, none of these $V_{f}$ values was significantly different from zero $(\mathrm{p}>0.05)$ due to the substantial variation around the mean (Fig. 4). The overall effect size of all simple compounds was 0.04 and was not significantly different from zero $(\mathrm{p}>0.88)$. Conversely, mean effect size of our DOC leachate was -0.43 and significantly different from zero $(\mathrm{p}<0.05)$. The effect size of the leachate DOC $V_{f}$ from our study did not significantly differ from those of the individual simple 
Table 2 Whole-stream and biofilm uptake of the tDOC tracer $(n=3$; mean \pm 1 SD) after $24 \mathrm{~h}$ of tracer addition

\begin{tabular}{|c|c|c|}
\hline Whole-stream DOC uptake & Forest & Agriculture \\
\hline $\mathrm{S}_{\mathrm{w}}(\mathrm{m})$ & $263 \pm 15$ & $668 \pm 222 * *^{a}$ \\
\hline$V_{f}\left(m m \min ^{-1}\right)$ & $1.86 \pm 0.10$ & $1.22 \pm 0.34 *$ \\
\hline $\mathrm{U}_{\text {tot }}\left(\mathrm{mg} \mathrm{m}^{-2} \mathrm{day}^{-1}\right)$ & $18.92 \pm 1.02$ & $2.97 \pm 0.81 * * *$ \\
\hline \multicolumn{3}{|l|}{ Net-DOC mineralization } \\
\hline $\operatorname{Min}_{\text {net }}\left(\mathrm{mg} \mathrm{m}^{-2}\right.$ day $\left.^{-1}\right)\left(\%\right.$ of $\left.U_{\text {tot }}\right)$ & $3.49 \pm 0.19(18)$ & $1.75 \pm 0.47 * *(59)$ \\
\hline \multicolumn{3}{|l|}{ Biofilm DOC uptake } \\
\hline Stream $U_{b}\left(\mathrm{mg} \mathrm{m}^{-2}\right.$ day $\left.^{-1}\right)\left(\%\right.$ of $\left.U_{\text {tot }}\right)$ & $0.70 \pm 0.29$ & $0.40 \pm 0.05$ \\
\hline Flume $\mathrm{U}_{\mathrm{b}}\left(\mathrm{mg} \mathrm{m}^{-2} \mathrm{day}^{-1}\right)$ & $0.40 \pm 0.20$ & $0.23 \pm 0.07$ \\
\hline
\end{tabular}

Spiraling metrics were compared between streams with t-tests

$S_{W}$ uptake length, $V_{f}$ uptake velocity, $U_{t o t}$ whole-stream areal uptake, $M i n_{n e t}$ net-DOC mineralization rate measured as DIC, $U_{b}$ areal uptake of epilithic biofilms

${ }^{\mathrm{a}} \mathrm{S}_{\mathrm{W}}$ was $\ln$-transformed to reach normality for the ANOVA

$* \mathrm{p}<0.05 ; * * \mathrm{p}<0.01 ; * * * \mathrm{p}<0.001$

Fig. 3 Temporal development of tracer standing stocks in biofilms of flumes and reaches of the forest and agricultural stream. Shown are means \pm 1SD from triplicated measurements. The mean (dashed line) and SD (grey bar) of the background-corrected ${ }^{13} \mathrm{C}$ DOC tracer flux is given for comparison. Note that panels are scaled individually to improve readability
Forest
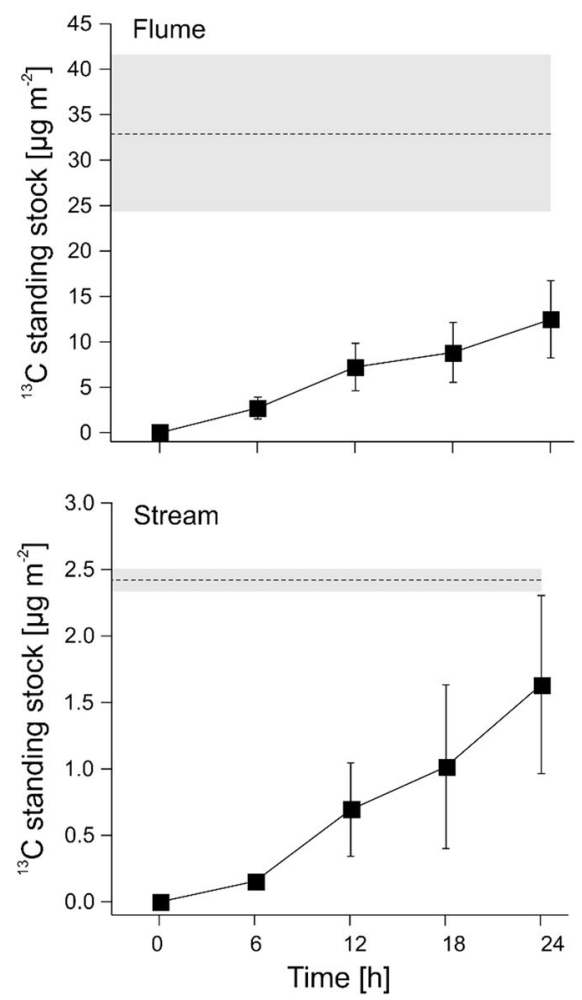

Agricultural
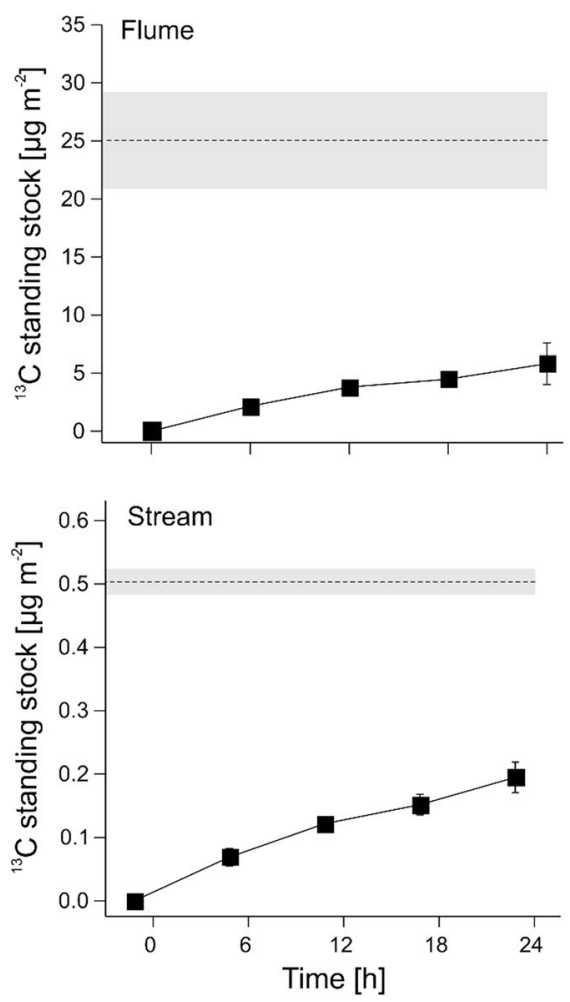

compounds ( $\mathrm{p}>0.05)$ as well as from the grand mean for simple compounds $(\mathrm{p}=0.090)$.
Benthic biofilm attributes

Compared to the forest stream, biofilms in the agricultural stream were best characterized by lower $\mathrm{C}: \mathrm{N}, \mathrm{C}: \mathrm{P}$ and $\mathrm{N}: \mathrm{P}$ ratios, AFDM, and bacterial OTU 


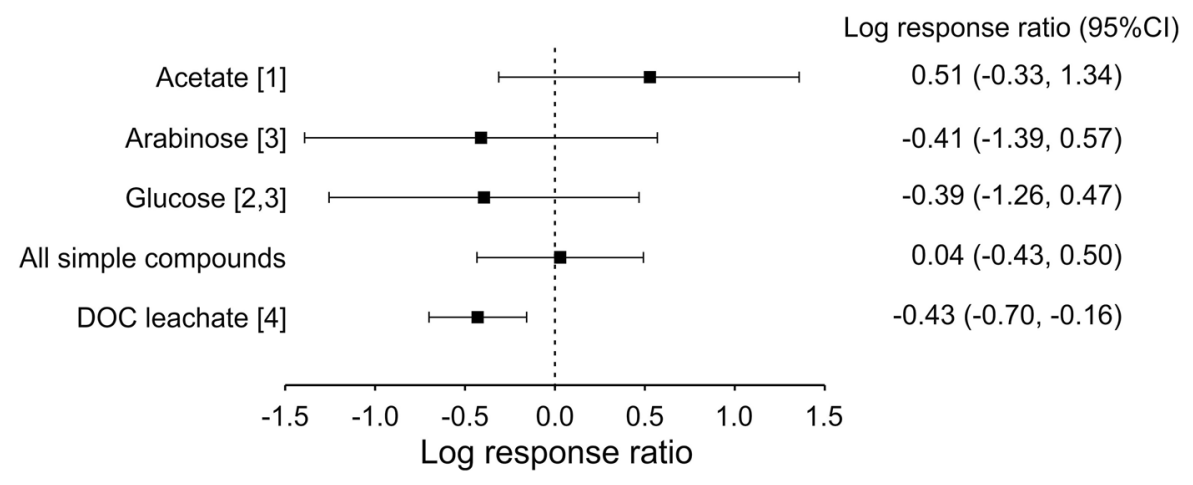

Fig. 4 Synthesis of the response of DOC uptake velocity (log response ratio $\pm 95 \%$ confidence interval $(\mathrm{CI})$ ) to agricultural land use, as estimated from studies presenting replicated wholestream additions of simple DOC compounds (acetate, arabinose and glucose) and leachates. The dashed line (mean effect size $=0$ ) indicates no effect of DOC compound on uptake velocity. Data from [1] Newbold et al. (2006), [2] Bechtold et al. (2012), [3] Johnson et al. (2009a), and [4] this study

Table 3 Biofilm characteristics (mean $\pm 1 \mathrm{SD}$ ), number of samples given in brackets for each column

\begin{tabular}{|c|c|c|c|c|}
\hline & \multicolumn{2}{|l|}{ Forest } & \multicolumn{2}{|l|}{ Agriculture } \\
\hline & Stream (12) & Flume (12) & Stream (11) & Flume (11) \\
\hline $\operatorname{AFDM}\left(\mathrm{mg} \mathrm{m}^{-2}\right)$ & $1.8 \pm 0.8$ & $3.9 \pm 1.4$ & $0.5 \pm 0.1$ & $1.5 \pm 0.9$ \\
\hline $\mathrm{C}: \mathrm{N}$ ratio (molar) & $10.4 \pm 1.5$ & $13.6 \pm 2.8$ & $8.2 \pm 1.4$ & $9.3 \pm 1.1$ \\
\hline $\mathrm{C}: \mathrm{P}$ ratio (molar) & $399.1 \pm 85.5$ & $411.9 \pm 112.6$ & $123.0 \pm 33.8$ & $104.6 \pm 26.2$ \\
\hline $\mathrm{N}: \mathrm{P}$ ratio (molar) & $38.6 \pm 7.8$ & $31.6 \pm 11.2$ & $15.9 \pm 6.7$ & $11.7 \pm 4.7$ \\
\hline Bact. density $\left(10^{5}\right.$ cells $\left.\mathrm{mm}^{-2}\right)$ & $1.0 \pm 0.4$ & $1.0 \pm 0.3$ & $4.3 \pm 1.7$ & $2.5 \pm 0.8$ \\
\hline Bact. production (mg C m ${ }^{-2}$ day $^{-1}$ ) & $12.5 \pm 8.9$ & $12.7 \pm 9.8$ & $35.3 \pm 14.4$ & $30 \pm 11.9$ \\
\hline Chl-a $\left(\mathrm{mg} \mathrm{m}^{-2}\right)$ & $1.1 \pm 0.6$ & $1.4 \pm 0.4$ & $0.3 \pm 0.6$ & $1.0 \pm 0.9$ \\
\hline $\operatorname{GPP}\left(\mathrm{mg} \mathrm{O}_{2} \mathrm{~m}^{-2} \mathrm{~h}^{-1}\right)$ & $18.4 \pm 15.6$ & $15.9 \pm 6.5$ & $22.9 \pm 6.5$ & $15.3 \pm 7.8$ \\
\hline $\mathrm{R}\left(\mathrm{mg} \mathrm{O} \mathrm{O}^{-2} \mathrm{~h}^{-1}\right)$ & $3.7 \pm 3.5$ & $2.4 \pm 2.7$ & $8.3 \pm 3.8$ & $6.9 \pm 5.2$ \\
\hline Bacterial diversity (No. OTUs) & $26.8 \pm 11.8$ & $30.2 \pm 11.9$ & $16.4 \pm 9.1$ & $15.2 \pm 5.7$ \\
\hline Algal diversity (No. OTUs) & $53.4 \pm 14.4$ & $49.4 \pm 17.0$ & $33.5 \pm 11.8$ & $48.7 \pm 15.9$ \\
\hline
\end{tabular}

AFDM ash-free dry mass, Bact. bacterial, $C h l-a$ chlorophyll a, GPP gross-primary production, $R$ respiration

richness; and by higher bacterial density and bacterial production (Table 3, Fig. 5). These trends held for both stream tiles and flume tiles (Table 3, Fig. 5). Stream type (forest or agricultural stream) was the most important parameter explaining the largest part of the variance in biofilm structure ( $\mathrm{Df}=1$, $\left.\mathrm{R}^{2}=0.37, \mathrm{~F}=32.3, \mathrm{p}<0.001\right)$. With a much lower explained variance, we also found a significant effect of tile location (streams or flumes, Df $=1, \mathrm{R}^{2}=0.07$, $\mathrm{F}=6.0, \mathrm{p}<0.001)$ and a significant effect of the interaction between stream type and the addition of the tDOC tracer (with or without tDOC tracer addition, Df $=1, R^{2}=0.05, F=1.3, p=0.004$ ) (see Table $\mathrm{S} 1$ in the Supplementary Material for details).
Bacterial production correlated negatively with $\mathrm{U}_{\mathrm{b}}$ (Fig. 6a), whereas N:P and C:P ratios correlated positively with $\mathrm{U}_{\mathrm{b}}$ (Fig. $6 \mathrm{~b}, \mathrm{c}$ ). Further variables of biofilm structure of stream and flume tiles differed significantly in both streams (Table S1). However, differences in biofilm structure between stream tiles and flume tiles only explained $7 \%$ of the variance of the entire biofilm structure dataset (Table S1), and did not correlate with $\mathrm{U}_{\mathrm{b}}$ (Fig. 6). We further explored these differences within a PCA (Fig. 5): for the flume tiles, GPP with Chl-a positively correlated, and both negatively correlated with algal OTU richness. These correlations were less apparent for the stream tiles. The fact that the differences between biofilms on 


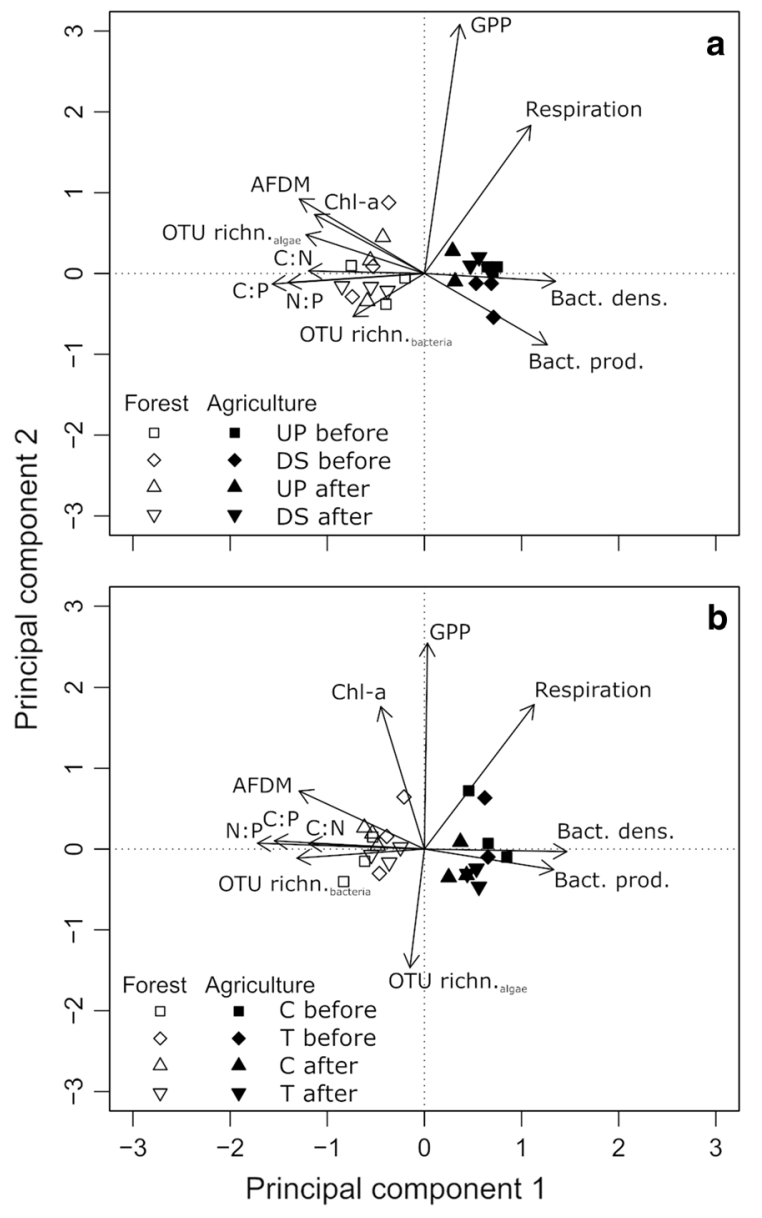

Fig. 5 Ordinations of biofilm characteristics based on a principal component analyses for stream tiles (a, 1. Axis = $48 \%, 2$. Axis $=13 \%$ explained variance) or flume tiles (b, 1 . Axis $=42 \%, 2$. Axis $=17 \%$ explained variance). The legends show the character of the points for the different types of samples. See Table S1 for tests of factor effects on the biofilm characteristics. Forest forest stream, Agriculture agricultural stream, $U P$ upstream, $D S$ downstream, $C$ control, $T$ treatment, before before DOC addition, after after DOC addition. AFDM Ash-free dry mass, Bact. dens. bacterial density, Bact. prod. Bacterial production, Chl-a chlorophyll a, GPP grossprimary production, $O T U$ richn.bacteria number of bacterial OTUs, OTU richn. algae number of algal OTUs, $C: N$ C:N molar ratio, $N: P \mathrm{~N}: \mathrm{P}$ molar ratio, $C: P \mathrm{C}: \mathrm{P}$ molar ratio

flume and stream tiles weakly interacted with stream identity and sampling time can also be noted in the PCA (Fig. 5).
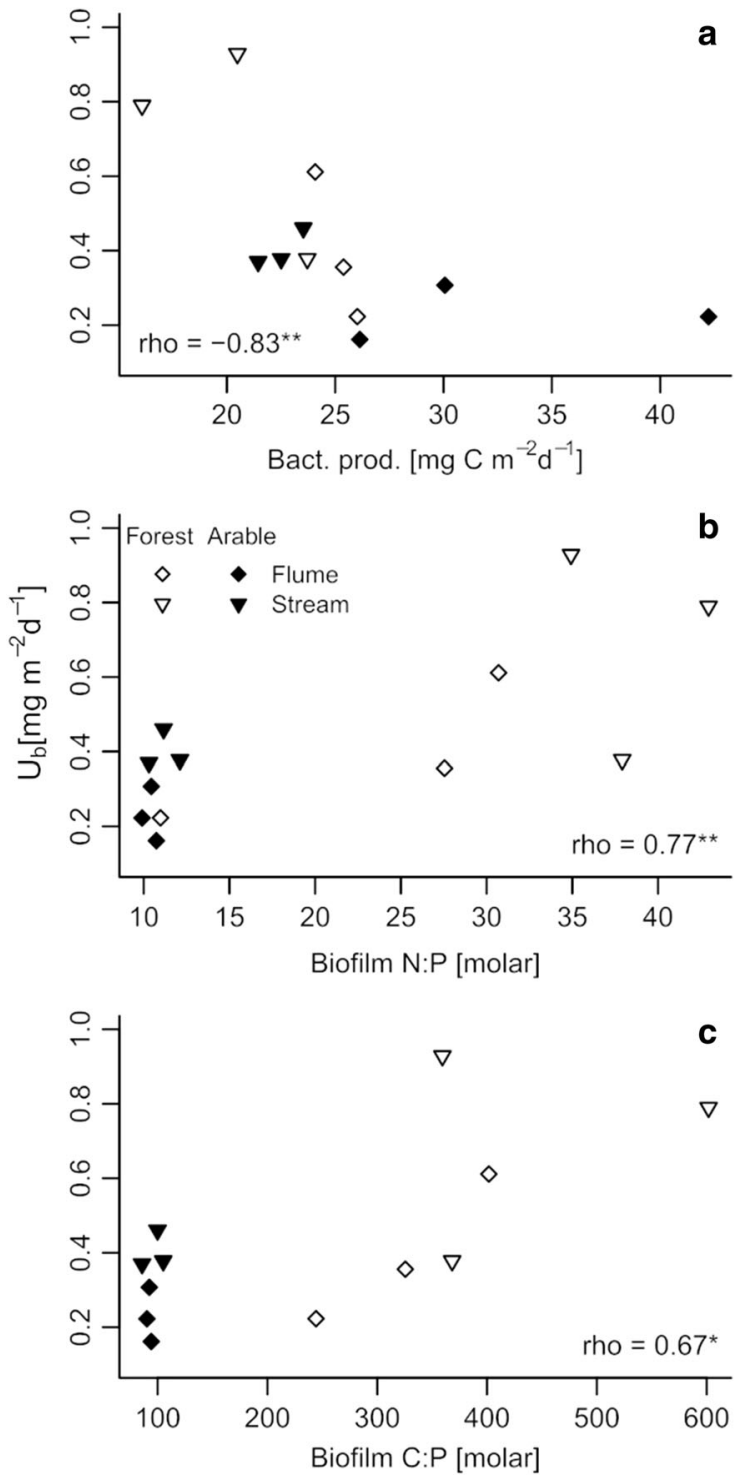

Fig. 6 Correlations of areal biofilm uptake $\left(U_{b}\right)$ with bacterial production (a), biofilm N:P ratio (b) and biofilm C:P ratio (c). Spearman's rho of the correlations is given. $* \mathrm{p}=0.01-0.05$, $* * p=0.001-0.01$. The points shown in the top left of panel $b$ are legend points, not data points

\section{Discussion}

We hypothesized that a higher benthic biofilm autotrophy would cause lower whole-stream DOC uptake in the agricultural stream than in the reference forest stream and that this difference in whole-stream uptake would be reinforced by the altered hydromorphology of the agricultural stream. Concerning wholestream tDOC tracer uptake $\left(\mathrm{U}_{\mathrm{tot}}\right)$, our hypothesis was 
supported by the data: in the forest stream, wholestream uptake was six times higher, uptake length was 2.5 times shorter, and tDOC tracer uptake velocity $\left(\mathrm{V}_{\mathrm{f}}\right)$ was 1.5 times higher than in the agricultural stream. However, our data on tDOC tracer uptake by benthic biofilms $\left(\mathrm{U}_{\mathrm{b}}\right)$ did not support this hypothesis, as we found that tDOC uptake by biofilms did not differ between streams and that the biofilms in were not crucial for $\mathrm{U}_{\text {tot }}$. Furthermore, we found differences in hydromorphology, but these only amounted to a relatively small decrease in transient storage in the agricultural stream relative to the forest stream. Therefore, neither tDOC uptake by benthic biofilms, nor strong differences in transient storage can fully explain the apparent strong difference in $\mathrm{U}_{\text {tot }}$ between the forest stream and agricultural stream. In the following discussion, we will further assess the links between benthic biofilms, hydromorphology and $\mathrm{U}_{\text {tot }}$; and will assess potential alternative mechanisms explaining the difference in $\mathrm{U}_{\text {tot }}$ between the two streams.

Mechanisms linking hydromorphology, benthicbiofilm uptake and whole-stream uptake

Four non-mutually exclusive mechanisms that may explain the low contribution of $\mathrm{U}_{\mathrm{b}}$ to $\mathrm{U}_{\mathrm{tot}}$ and the weak link between transient storage and $\mathrm{U}_{\text {tot }}$ :

(i) Benthic biofilms can have high internal autotrophic DOC production and/or storage potential (Romaní et al. 2004; Lyon and Ziegler 2009), reducing their need for external tDOC like the tDOC tracer used here (Ziegler et al. 2009; Graeber et al. 2018).

(ii) Within the stream, un-sampled populations like planktonic bacteria (Graeber et al. 2018) or benthic biofilms on organic substrates could have controlled $\mathrm{U}_{\text {tot }}$ in the two studied streams. Planktonic bacteria within stream surface water can be highly responsive to leaf leachate tDOC like the one used here (Graeber et al. 2018). Using the model calculations from Graeber et al. (2018), pelagic bacteria in stream water could be responsible for between $17-56 \%$ and $33-77 \%$ of the $U_{\text {tot }}$ in the forest stream and agricultural stream, respectively. In contrast, our tracer measurements found that $U_{b}$ of the epilithic biofilms in the benthic zone was responsible for only $4 \%$ (forest stream) and 13\% (agricultural stream) of the $\mathrm{U}_{\text {tot }}$. Measured benthic plus calculated pelagic tDOC uptake could account for up to $69 \%$ (forest stream) and 90\% (agricultural stream) of $\mathrm{U}_{\text {tot }}$. Benthic biofilms on organic surfaces may also affect tDOC uptake (Johnson et al. 2009b). However, biofilms on organic substrates are less likely to be important for to rely on stream water tDOC than biofilms on mineral substrates, as the organic substrate can also serve as an organic carbon source (Pastor et al. 2014). Furthermore, mineral substrates dominated the benthic zone in the studied streams, making benthic organic substrates unlikely to host a significant portion of the stream biofilm biomass.

(iii) The hyporheic zone can have a high DOC retention potential (Findlay and Sobczak 1996; Sobczak and Findlay 2002) and a clear relationship between transient storage times and uptake has been shown for inorganic nutrients and may also be valid for tDOC (Gücker and Boëchat 2004; Bernot et al. 2006). This relationship would suggest that the greater transient storage in the hyporheic zone of the forest stream $\left(\mathrm{TSI}_{\text {norm }}=10.2\right)$ compared to the agricultural stream (TSI norm= 8.0) (Ward et al. 2013) may have amplified the relative role of hyporheic zone biofilms and reduced the effect of benthic biofilm $\mathrm{U}_{\mathrm{b}}$ on $\mathrm{U}_{\mathrm{tot}}$. However, compared to the literature, the spread of TSI $_{\text {norm values between the two }}$ streams of our study is small: an investigation of three stretches of an unmanaged mountain stream revealed $\mathrm{TSI}_{\text {norm }}$ values between 1.7 and 17.7 (Ward et al. 2013). Furthermore, a study of land use effects on TSI norm $_{\text {found that }}$ urban reaches exhibited values of $<5$, that agricultural reaches exhibited a TSI $_{\text {norm }}$ of 6 to 7 and that forest streams showed a TSI norm of up to 20 (Gooseff et al. 2007). The small

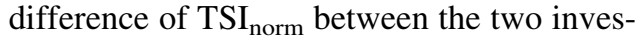
tigated streams suggests a small but defined difference in transient storage but likely cannot fully explain the large difference in $\mathrm{U}_{\text {tot }}$. In addition, different biological activity in the hyporheic zones of the two streams 
likely further affected tDOC uptake. This assumption is backed up by a combined field and mesocosm study, which found that the percentage of DOC loss along natural hyporheic flow paths was not a function of hydrological or nutritional variables, such as water residence time or DOC concentration, but likely was linked to variations in hyporheic microbial metabolism of the investigated streams (Sobczak and Findlay 2002).

(iv) Bacterial respiration can take up to $24 \mathrm{~h}$ to respond to tracer additions (del Giorgio and Cole 1998), meaning that microbial consumption could be the dominant retention mechanism in our $24 \mathrm{~h}$ experiment. The likely delayed response helps explain why net mineralization (18\% of $U_{\text {tot }}$ in the forest stream) was here lower than expected for typical microbial growth efficiencies (del Giorgio and Cole 1998).

In conclusion, the mentioned mechanisms imply a significant pelagic and/or hyporheic zone contribution to the efficient $U_{\text {tot }}$ in the forest stream. This conclusion highlights the need for future research that robustly quantifies, how the three stream compartments (surface water, benthos, hyporheic zone) interact to dictate $\mathrm{U}_{\text {tot }}$.

Comparison of whole-stream tDOC uptake with other studies

The apparent difference in $V_{f}$ between the forest and agricultural stream in our study contradicts previous studies showing only negligible effects of land use on in-stream tDOC uptake. However, it is difficult to evaluate if differences between studies are due to the nature of the DOC tracer or stream properties. Since our data stems from a regional comparison of only two streams, future studies should assess if the shift towards smaller tDOC $\mathrm{V}_{\mathrm{f}}$ in agricultural streams suggested here holds true for other streams and regions.

Concerning the lability of different DOC tracers, a recent meta-analysis of different DOC tracers found that the median whole-stream $\mathrm{V}_{\mathrm{f}}$ of labile compounds (2.94 $\mathrm{mm} \mathrm{min}^{-1}$ ) was faster than that of leachates $\left(1.11 \mathrm{~mm} \mathrm{~min}^{-1}\right)$, independent of catchment land use (Mineau et al. 2016). Our measured DOC $\mathrm{V}_{\mathrm{f}}(1.22$ and
$1.87 \mathrm{~mm} \mathrm{~min}^{-1}$ in the agricultural and forest stream, respectively) are between the reported values, suggesting that our leachate tracer contained both labile and semi-labile compounds. Our data synthesis supports the conjecture that the type of DOC tracer affects its uptake, as it showed that agricultural land use either decreased or increased $V_{f}$ depending on the used tracer.

Even within studies using simple model compounds substantial $\mathrm{V}_{\mathrm{f}}$ variations were apparent. These variations suggest that other factors (e.g., seasonality) may also regulate differences between forested and agricultural streams, as shown for other ecosystem functions, such as nitrate uptake (Rode et al. 2016). The intensity of agricultural impact differed between the studies, which could also contribute to the overall $\mathrm{V}_{\mathrm{f}}$ variability: agricultural land use ranges from cattle grazing (modest nutrient enrichment) to intense crop production (substantial hydromorphological degradation and eutrophication), such as the agricultural stream studied here. Logically, differences between forest and agricultural streams should increase with increasing agricultural intensity. However, our study does not allow for generalizing across streams with different agricultural practices or across seasons due to the small sample size (one stream per land-use type). In addition to the role of the tDOC tracer type, the role of agricultural land use intensity and seasonality on DOC processing in streams still largely remain unknown.

\section{Benthic biofilm attributes}

The biofilms differed between the two streams. Biofilms on both the stream and flume tiles were characterized by lower bacterial OTU richness and higher bacterial abundance and bacterial production in the agricultural stream relative to the forest stream. The lower bacterial OTU richness may be related to a lower diversity of bacterial sources or a stronger environmental selection of bacteria in the agricultural stream (Besemer et al. 2013; Niño-García et al. 2016).

The low biofilm C:N, C:P, and N:P ratios within the area of the Redfield ratio (Sterner and Elser 2002) indicate a generally good level of supply and storage of nitrogen and phosphorus in the agricultural stream. In contrast, we found higher $\mathrm{N}: \mathrm{P}$ and $\mathrm{C}: \mathrm{P}$ ratios in the forest stream, likely due to phosphorus limitation resulting from the lower SRP concentrations (below 
detection limit in the forest stream and $16 \mu \mathrm{g} \mathrm{L} \mathrm{L}^{-1}$ in the agricultural stream).

In contrast to our expectation, benthic biofilm autotrophy (GPP and Chl-a) was not higher for biofilms in the agricultural stream than in the forest stream. This result is in line with results from other streams in the same catchment, where differences in light levels did not affect Chl-a concentration (Kamjunke et al. 2015b). However, in a large interbiome comparison, a relatively strong correlation between photosynthetically active radiation (PAR) and whole-stream GPP was found (Bernot et al. 2010), and PAR strongly shifts seasonally (Bernhardt et al. 2018). Therefore, differences in sampling date could mask differences in GPP and Chl-a. The agricultural stream was sampled 4 weeks earlier than the forested stream, which may lead to differences in light availability and water temperature. However, at the respective sampling date, the agricultural stream had $28 \mathrm{~min}$ less daylight than the forest stream, which likely did not affect GPP or Chl-a. More importantly, the consistency of the in-stream measurements with those measured in the flumes, where daylight hours were controlled, means that such a seasonal light effect cannot explain the observed differences in biofilms and tDOC between the two streams. The differences in sampling date may also have affected the stream water temperatures; however, we only measured a difference of $2{ }^{\circ} \mathrm{C}$, which we deem too low to influence the biofilm metabolism significantly.

The negative correlation between biofilm tDOC uptake and bacterial production suggests that less developed biofilms with lower bacterial production drove demand for external $\mathrm{C}$ sources, while more developed biofilms had sufficient internal $\mathrm{C}$ storage (Graeber et al. 2018) and autotrophic DOC production for heterotrophic use (Ziegler et al. 2009). Additional external sources like particulate organic carbon could also reduce tDOC uptake by increasing bacterial production. However, AFDM (which reflects the organic carbon stock of the biofilm, plus sedimentary particulate organic carbon trapped on the biofilm) was not correlated to tDOC uptake, making this an unlikely explanation. Alternatively, mixotrophic algae can also proliferate in biofilms and utilize DOC by osmotrophy (Tittel et al. 2009), and thus contribute to the negative correlation between biofilm bacterial production and DOC uptake. Hence, while logical explanations for the observed negative correlation exist, the exact mechanism cannot be identified with our data.

Biofilm C:P and $\mathrm{N}: \mathrm{P}$ ratios correlated positively with tDOC uptake. However, the data was split into two distinct groups of $\mathrm{C}: \mathrm{P}$ and $\mathrm{N}: \mathrm{P}$ ratios, with the ratios of the agricultural stream being lower than the ones of the forested stream. Hence, attributing causality to these correlations is difficult. Mindful of this uncertainty and in the light of the positive correlation between bacterial production and DOC uptake, we suggest that the positive correlation between the two ratios and may be related to the developmental state of the biofilm. Specifically, better-developed biofilms with higher bacterial production may be less dependent on external tDOC (Graeber et al. 2018) and may have lower C:P and N:P due to storage of $\mathrm{N}$ and $\mathrm{P}$ by algae (Frost et al. 2005), resulting in the positive correlation between the two ratios and tDOC uptake. This explanation does not imply a causal relationship between $\mathrm{C}: \mathrm{N}$ and $\mathrm{N}: \mathrm{P}$ ratios and $\mathrm{U}_{\mathrm{b}}$ but suggests that all three parameters reflect the developmental stage of the biofilms (Sterner and Elser 2002). Our results cannot finally disentangle the effect of land use on biofilm structure, and tDOC uptake. Only few studies link land use, biofilm stoichiometry, and biofilm functioning and further investigations are needed to fill this gap of knowledge.

The relationships between benthic biofilm structure and tDOC uptake may translate into changes of the benthic food web configuration, linking the delivery of tDOC from the catchment to the growth of benthic primary consumers and higher trophic levels. However, the small contribution of benthic biofilms to $U_{\text {tot }}$ means that the suggested shifts in benthic biofilm structure and $\mathrm{U}_{\mathrm{b}}$ between land use types do not translate into differences in whole-stream DOC uptake.

Our data suggest that the biofilms on the tiles in stream-side flumes mostly reflect the stream-specific differences of biofilm structure detrermined for the tiles positioned directly in the streams. We also found that $U_{b}$ was low on all tiles in comparison to $U_{\text {tot }}$ in both streams, however, with generally higher biofilm $\mathrm{U}_{\mathrm{b}}$ uptake for the stream tiles compared to the flume tiles. This led us to the conclusion that tiles in streamside flumes can generally be used to mimic the effects of a given factor (such as land use) on biofilm structure and functioning in the stream itself, but that a perfect representation of stream biofilms cannot be expected. 


\section{Conclusions}

There are three significant implications for our understanding of how human activities impact stream tDOC dynamics that emerge from this two-stream comparison. First, benthic epilithic biofilms in both streams played a smaller role in tDOC uptake than predicted from previous studies. The missing importance of such biofilms highlights the need to include all stream compartments, i.e., the water column, other benthic substrates and the hyporheic zones, to assess stream compartments and state factors controlling whole-stream tDOC cycling accurately. Second, our results point towards a significant human impact on stream tDOC cycling, as $U_{\text {tot }}$ was much lower in the agricultural stream than in the forest stream. This result implies that reduced tDOC uptake potential in agricultural streams could be a cause of increasing DOC loads to downstream receiving waters. However, this two-stream comparison is a first step towards an improved understanding of land-use effects on stream tDOC uptake, and future studies should assess such effects in other streams, biomes and climate zones. Furthermore, the data synthesis suggests that tracer quality combined with differences in the characteristics of the study sites affects tDOC dynamics and that future studies should consider the type of DOC tracer when assessing land-use effects on tDOC uptake.

Acknowledgements We thank Sven Bauth, Martin Diener, Steffen Geisthard, Sebastian Hasseluhn, Andrea Hoff, Ute Kuhlicke, Ute Link, Ines Locker, Thomas Neu, Nicole Oberhoffner, Lino Parlow and Ute Risse-Buhl for their invaluable help with sampling and sample preparation. Robert van Geldern and Christian Hanke carefully analyzed the ${ }^{13} \mathrm{C}$ DOC samples and provided valuable advice on sample preparation and data interpretation. This study was funded by a grant of the German Science Foundation (Grant No. BR 4358/1-1). B. Gücker was supported by the Foundation for Research Support of the Federal State of Minas Gerais (FAPEMIG, Grant No. CRA PPM PPM-00386-18 and CRA 11/12) and the Brazilian National Council for Scientific and Technological Development (CNPq, 305712/2018-7). We want to thank three anonymous reviewers and the handling editor, Jonathan Sanderman, whose valuable comments strongly improved this manuscript.

Open Access This article is distributed under the terms of the Creative Commons Attribution 4.0 International License (http:// creativecommons.org/licenses/by/4.0/), which permits unrestricted use, distribution, and reproduction in any medium, provided you give appropriate credit to the original author(s) and the source, provide a link to the Creative Commons license, and indicate if changes were made.

\section{References}

Anderson MJ (2001) A new method for non-parametric multivariate analysis of variance. Austral Ecol 26:32-46

Battin TJ, Besemer K, Bengtsson MM et al (2016) The ecology and biogeochemistry of stream biofilms. Nat Rev Microbiol 14:251-263. https://doi.org/10.1038/nrmicro.2016.15

Bechtold HA, Marcarelli AM, Baxter CV, Inouye RS (2012) Effects of N, P, and organic carbon on stream biofilm nutrient limitation and uptake in a semi-arid watershed. Limnol Oceanogr 57:1544-1554. https://doi.org/10.4319/ lo.2012.57.5.1544

Bernhardt ES, Heffernan JB, Grimm NB et al (2018) The metabolic regimes of flowing waters. Limnol Oceanogr 63:S99-S118. https://doi.org/10.1002/lno.10726

Bernot MJ, Tank JL, Royer TV, David MB (2006) Nutrient uptake in streams draining agricultural catchments of the midwestern United States. Freshw Biol 51:499-509. https://doi.org/10.1111/j.1365-2427.2006.01508.x

Bernot MJ, Sobota DJ, Hall RO et al (2010) Inter-regional comparison of land-use effects on stream metabolism. Freshw Biol 55:1874-1890. https://doi.org/10.1111/j. 1365-2427.2010.02422.x

Besemer K, Singer G, Quince C et al (2013) Headwaters are critical reservoirs of microbial diversity for fluvial networks. Proc R Soc B Biol Sci 280:20131760. https://doi. org/10.1098/rspb.2013.1760

Blann KL, Anderson JL, Sands GR, Vondracek B (2009) Effects of agricultural drainage on aquatic ecosystems: a review. Crit Rev Environ Sci Technol 39:909-1001. https://doi. org/10.1080/10643380801977966

Boëchat IG, Krüger A, Giani A et al (2011) Agricultural landuse affects the nutritional quality of stream microbial communities. FEMS Microbiol Ecol 77:568-576. https:// doi.org/10.1111/j.1574-6941.2011.01137.x

Carter JF, Fry B (2013) “Do it yourself” reference materials for $\delta 13 \mathrm{C}$ determinations by isotope ratio mass spectrometry. Anal Bioanal Chem 405:4959-4962. https://doi.org/10. 1007/s00216-013-6851-z

Collins SM, Sparks JP, Thomas SA et al (2016) Increased light availability reduces the importance of bacterial carbon in headwater stream food webs. Ecosystems 19:396-410. https://doi.org/10.1007/s10021-015-9940-3

Cribari-Neto F (2004) Asymptotic inference under heteroskedasticity of unknown form. Comput Stat Data Anal 45:215-233. https://doi.org/10.1016/S01679473(02)00366-3

del Giorgio PA, Cole JJ (1998) Bacterial growth efficiency in natural aquatic systems. Annu Rev Ecol Syst 29:503-541. https://doi.org/10.1146/annurev.ecolsys.29.1.503

DIN EN 1484 (1997) Guidelines for the determination of total organic carbon (TOC) and dissolved organic carbon (DOC) in water. European Committee for Standardization

Dodds WK, Smith VH, Lohman K (2002) Nitrogen and phosphorus relationships to benthic algal biomass in temperate streams. Can J Fish Aquat Sci 59:865-874. https://doi.org/ 10.1139/f02-063

Findlay S, Sobczak WV (1996) Variability in removal of dissolved organic carbon in hyporheic sediments. J N Am Benthol Soc 15:35-41. https://doi.org/10.2307/1467431 
Fox J, Weisberg S (2011) An R companion to applied regression, 2nd edn. Sage, Thousand Oaks

Frost PC, Hillebrand H, Kahlert M (2005) Low algal carbon content and its effect on the $\mathrm{C}$ : $\mathrm{P}$ stoichiometry of periphyton. Freshw Biol 50:1800-1807. https://doi.org/10. 1111/j.1365-2427.2005.01449.x

Gooseff MN, Hall RO, Tank JL (2007) Relating transient storage to channel complexity in streams of varying land use in Jackson Hole, Wyoming. Water Resour Res 43:W01417. https://doi.org/10.1029/2005WR004626

Graeber D, Gelbrecht J, Pusch MT et al (2012) Agriculture has changed the amount and composition of dissolved organic matter in Central European headwater streams. Sci Total Environ 438:435-446. https://doi.org/10.1016/j.scitotenv. 2012.08.087

Graeber D, Boëchat IG, Encina-Montoya F et al (2015a) Global effects of agriculture on fluvial dissolved organic matter. Sci Rep 5:16328. https://doi.org/10.1038/srep16328

Graeber D, Goyenola G, Meerhoff M et al (2015b) Interacting effects of climate and agriculture on fluvial DOM in temperate and subtropical catchments. Hydrol Earth Syst Sci 19:2377-2394. https://doi.org/10.5194/hess-19-2377-2015

Graeber D, Poulsen JR, Heinz M et al (2018) Going with the flow: planktonic processing of dissolved organic carbon in streams. Sci Total Environ 625:519-530. https://doi.org/ 10.1016/j.scitotenv.2017.12.285

Grant SB, Azizian M, Cook P et al (2018) Factoring stream turbulence into global assessments of nitrogen pollution. Science 359:1266-1269. https://doi.org/10.1126/science. aap8074

Gücker B, Boëchat IG (2004) Stream morphology controls ammonium retention in tropical headwaters. Ecology 85:2818-2827. https://doi.org/10.1890/04-0171

Gücker B, Boëchat IG, Giani A (2009) Impacts of agricultural land use on ecosystem structure and whole-stream metabolism of tropical Cerrado streams. Freshw Biol 54:2069-2085. https://doi.org/10.1111/j.1365-2427.2008. 02069.x

Heinz M, Graeber D, Zak D et al (2015) Comparison of organic matter composition in agricultural versus forest affected headwaters with special emphasis on organic nitrogen. Environ Sci Technol 49:2081-2090. https://doi.org/10. 1021/es505146h

Hothorn T, Bretz F, Westfall P (2008) Simultaneous inference in general parametric models. Biom J 50:346-363. https:// doi.org/10.1002/bimj.200810425

ISO 13395 (1996) Water quality-determination of nitrite nitrogen and nitrate nitrogen and the sum of both by flow analysis (CFA and FIA) and spectrometric detection. International Organization for Standardization

ISO 14911 (1998) Water quality-determination of dissolved $\mathrm{Li}+, \mathrm{Na}+, \mathrm{NH} 4+, \mathrm{K}+, \mathrm{Mn} 2+, \mathrm{Ca} 2+, \mathrm{Mg} 2+, \mathrm{Sr} 2+$ and $\mathrm{Ba} 2+$ using ion chromatography-method for water and waste water. International Organization for Standardization

ISO 6878 (2004) Water quality-determination of phosphorus-ammonium molybdate spectrometric method. International Organization for Standardization

Johnson LT, Tank JL, Arango CP (2009a) The effect of land use on dissolved organic carbon and nitrogen uptake in streams. Freshw Biol 54:2335-2350. https://doi.org/10. 1111/j.1365-2427.2009.02261.x

Johnson LT, Tank JL, Dodds WK (2009b) The influence of land use on stream biofilm nutrient limitation across eight North American ecoregions. Can J Fish Aquat Sci 66:1081-1094. https://doi.org/10.1139/F09-065

Kamjunke N, Herzsprung P, Neu TR (2015a) Quality of dissolved organic matter affects planktonic but not biofilm bacterial production in streams. Sci Total Environ 506-507:353-360. https://doi.org/10.1016/j.scitotenv. 2014.11.043

Kamjunke N, Mages M, Büttner O et al (2015b) Relationship between the elemental composition of stream biofilms and water chemistry - a catchment approach. Environ Monit Assess 187:432. https://doi.org/10.1007/s10661-0154664-6

Kelleher C, Wagener T, McGlynn B et al (2013) Identifiability of transient storage model parameters along a mountain stream. Water Resour Res 49:5290-5306. https://doi.org/ 10.1002/wrcr.20413

Lyon DR, Ziegler SE (2009) Carbon cycling within epilithic biofilm communities across a nutrient gradient of headwater streams. Limnol Oceanogr 54:439-449. https://doi. org/10.4319/lo.2009.54.2.0439

Mason SJK, McGlynn BL, Poole GC (2012) Hydrologic response to channel reconfiguration on silver Bow Creek, Montana. J Hydrol 438-439:125-136. https://doi.org/10. 1016/j.jhydrol.2012.03.010

Mineau MM, Rigsby CM, Ely DT et al (2013) Chronic catchment nitrogen enrichment and stoichiometric constraints on the bioavailability of dissolved organic matter from leaf leachate. Freshw Biol 58:248-260. https://doi.org/10. 1111/fwb. 12054

Mineau MM, Wollheim WM, Buffam I et al (2016) Dissolved organic carbon uptake in streams: a review and assessment of reach-scale measurements: DOC uptake in streams. J Geophys Res Biogeosci 121:2019-2029. https://doi.org/ 10.1002/2015JG003204

Mulholland PJ, Valett HM, Webster JR et al (2004) Stream denitrification and total nitrate uptake rates measured using a field N-15 tracer addition approach. Limnol Oceanogr 49:809-820. https://doi.org/10.4319/lo.2004.49.3.0809

Newbold JD, Bott TL, Kaplan LA et al (2006) Uptake of nutrients and organic $\mathrm{C}$ in streams in New York City drinking-water-supply watersheds. J N Am Benthol Soc 25:998-1017. https://doi.org/10.1899/08873593(2006)025\%5b0998:UONAOC\%5d2.0.CO;2

Niño-García JP, Ruiz-González C, del Giorgio PA (2016) Interactions between hydrology and water chemistry shape bacterioplankton biogeography across boreal freshwater networks. ISME J. https://doi.org/10.1038/ismej.2015.226

Oksanen J, Blanchet FG, Kindt R, et al (2015) Vegan: community ecology package

Pastor A, Compson ZG, Dijkstra P et al (2014) Stream carbon and nitrogen supplements during leaf litter decomposition: contrasting patterns for two foundation species. Oecologia 176:1111-1121. https://doi.org/10.1007/s00442-0143063-y

Prairie YT (2008) Carbocentric limnology: looking back, looking forward. Can J Fish Aquat Sci 65:543-548. https:// doi.org/10.1139/f08-011 
Qu X, Ren Z, Zhang H et al (2017) Influences of anthropogenic land use on microbial community structure and functional potentials of stream benthic biofilms. Sci Rep 7:15117. https://doi.org/10.1038/s41598-017-15624-x

Quinn G, Keough MJ (2002) Experimental design and data analysis for biologists, 1st edn. Cambridge University Press, Cambridge

R Core Team (2019) R: a language and environment for statistical computing. R Foundation for Statistical Computing, Vienna

Rode M, Angelstein SH, Anis MR et al (2016) Continuous instream assimilatory nitrate uptake from high-frequency sensor measurements. Environ Sci Technol 50:5685-5694. https://doi.org/10.1021/acs.est.6b00943

Romaní AM, Guasch H, Muñoz I et al (2004) Biofilm structure and function and possible implications for riverine DOC dynamics. Microb Ecol 47:316-328. https://doi.org/10. 1007/s00248-003-2019-2

Runkel RL (1998) One-dimensional transport with inflow and storage (OTIS): a solute transport model for streams and rivers. US Department of the Interior, US Geological Survey

Sobczak WV, Findlay S (2002) Variation in bioavailability of dissolved organic carbon among stream hyporheic flowpaths. Ecology 83:3194-3209

Stanley EH, Powers SM, Lottig NR et al (2012) Contemporary changes in dissolved organic carbon (DOC) in humandominated rivers: is there a role for DOC management? Freshw Biol 57:26-42. https://doi.org/10.1111/j.13652427.2011.02613.x

Sterner RW, Elser JJ (2002) Ecological stoichiometry: the biology of elements from molecules to biosphere. Princeton University Press, Princeton

Tank JL, Meyer JL, Sanzone DM et al (2000) Analysis of nitrogen cycling in a forest stream during autumn using a 15 N-tracer addition. Limnol Oceanogr 45:1013-1029. https://doi.org/10.4319/lo.2000.45.5.1013

Tank JL, Rosi-Marshall EJ, Griffiths NA et al (2010) A review of allochthonous organic matter dynamics and metabolism in streams. J N Am Benthol Soc 29:118-146. https://doi. org/10.1899/08-170.1
Tittel J, Wiehle I, Wannicke N et al (2009) Utilisation of terrestrial carbon by osmotrophic algae. Aquat Sci 71:46-54. https://doi.org/10.1007/s00027-008-8121-2

Viechtbauer W (2010) Conducting meta-analyses in R with the metafor package. J Stat Softw 36:1-48. https://doi.org/10. 18637/jss.v036.i03

Wagner K, Besemer K, Burns NR et al (2015) Light availability affects stream biofilm bacterial community composition and function, but not diversity. Environ Microbiol 17:5036-5047. https://doi.org/10.1111/1462-2920.12913

Ward AS, Gooseff MN, Voltz TJ et al (2013) How does rapidly changing discharge during storm events affect transient storage and channel water balance in a headwater mountain stream? Water Resour Res 49:5473-5486. https://doi.org/ 10.1002/wrcr.20434

Wiegner TN, Kaplan LA, Newbold JD, Ostrom PH (2005) Synthesis of a C-13-labeled tracer for stream DOC: labeling tulip poplar carbon with (CO2)-C-13. Ecosystems 8:501-511. https://doi.org/10.1007/s10021-003-0043-1

Williams CJ, Yamashita Y, Wilson HF et al (2010) Unraveling the role of land use and microbial activity in shaping dissolved organic matter characteristics in stream ecosystems. Limnol Oceanogr 55:1159-1171. https://doi.org/10.4319/ 10.2010.55.3.1159

Wilson HF, Xenopoulos MA (2009) Effects of agricultural land use on the composition of fluvial dissolved organic matter. Nat Geosci 2:37-41. https://doi.org/10.1038/ngeo391

Wollschläger U, Attinger S, Borchardt D et al (2017) The Bode hydrological observatory: a platform for integrated, interdisciplinary hydro-ecological research within the TERENO Harz/Central German Lowland Observatory. Environ Earth Sci 76:29. https://doi.org/10.1007/s12665-016-63275

Ziegler SE, Lyon DR, Townsend SL (2009) Carbon release and cycling within epilithic biofilms in two contrasting headwater streams. Aquat Microb Ecol 55:285-300. https://doi. org/10.3354/ame01299

Publisher's Note Springer Nature remains neutral with regard to jurisdictional claims in published maps and institutional affiliations. 